\title{
Borges’ Poetics of Visible Unrealities
}

\author{
Robin McAllister \\ Sacred Heart University, Fairfield, Connecticut, USA
}

\begin{abstract}
Close reading and inter-textual analysis of Borges' essays, fiction, and poetry suggest a poetics of visible unrealities, a fiction that calls attention to its own artifice. Borges's poetics of reading and dreaming require another poetics of the work as a text that calls attention to its own artifice. In reading Borges' fiction, the separate roles and identities of reader, writer, and work of fiction merge and exchange roles, powers, and identities and are transformed into a single act of dreaming, which assumes cosmogonic and apocalyptic risks. In the dominant role given to the reader, the work of fiction as an object or work of art does not exist unless it is read. There is no determinate text, only a version of our own we re-write and invent every time we read the text. The author's reading is not a spontaneous evocation of vision, but an artifice, as artificial as the writing of the fiction. As writers and readers we are composed of texts and schemata, alphabets and artifacts, not merely mental perceptions and ideas. The reader requires a prior text to copy, translate, and recreate, and that text only exists as a fictional microcosm in so far as it is being read by a Reader who is able to actualize the revelation only imminent within it.
\end{abstract}

Keywords: Borges, poetics, reading, Berkeley

He comprehended that the effort to mold the incoherent and vertiginous matter dreams are made of was the most arduous task a man could undertake, though he might penetrate all the enigmas of the upper and lower orders: much more arduous than weaving a rope of sand or coining the faceless wind. (Borges, 1962, “The Circular Ruins”)

It is hazardous to think that a co-ordination of words (philosophies are nothing else) can have much resemblance to the universe. It is also hazardous to think that one of those famous co-ordinations does not resemble it a little more than others, even in an infinitesimal way. (Borges, 1966, “Avatars of the Tortoise”)

\section{Introduction}

Dreaming and stories that are mere co-ordinations of words are clues to the riddle of Borges' poetics of fiction, his concepts about the roles of the writer and the reader in creating a work of fiction. In our ordinary world of reading Borges, we uncritically take for granted the separate existence of the story as an object apart from us, a book we are opening in our hands to begin reading, the previous existence of the writer who created it, and our own autonomous existence as readers about to sit down, momentarily try to detach our attention from the distractions of the actual reality surrounding us, and immerse ourselves in reading the story, momentarily and, alas, only temporarily leaving behind one reality and entering into the mode of consciousness we find in reading a work of fiction. But in the world of Borges' fiction all these separate roles and identities merge and exchange roles, powers, and identities. The separate existences of a reader, writer, and book are transformed into a single act of dreaming.

Any account of Borges' "poetics" of fiction, his concept-implicit or explicit in his stories, essays, and

Robin McAllister, associate professor, Department of English, Sacred Heart University. 
poems - of what the fiction is, must take into account not just the extraordinary role he attributes to the reader, but another almost hidden, often denied concept as well, the fiction, not just as a text, but as a work of art, a "co-ordination of words", that calls attention to its own artifice. However, the reader's power to dream the work of fiction into existence emerges as Borges' preferred poetics, and the idea of the work as a co-ordination of words is forgotten or repudiated. In the world of Borges' fiction, the reader can assume fantastic roles: A dreamer, a failed writer, an unrequited lover, and a blind "magus" who creates and destroys, a consciousness on the verge of vision and annihilation, a copier and a creator, a simulacrum dreamed into existence by a prior text, even a fictional role constructed out of literary topoi and metaphysical problems to resolve the problem of trying to represent a vision of the universe that cannot be put into words.

\section{The Role of the Reader}

One of these roles, the Reader as Writer, is the subject of a famous essay by the late Rodrigues Monegal (1972), who attributes the concept of the Reader as Writer to Gerard Genette:

...Criticism is an activity as imaginary as fiction or poetry... Nevertheless, it is possible to attempt another reading of these texts, and of the famous "Pierre Menard", and instead of taking literally the conclusions of those critical articles, or the ironies of the story, perhaps to see in these short pieces the foundation of another aesthetic discipline, based not on the creation of the literary work but on its reading —instead of an aesthetics of the work of art, an aesthetics of its reading. This approach to Borges' work has been favored by the Nouvelle Critique since Gerard Genette’s article, "La literature selon Borges". Taking as his starting point the final lines of "Pierre Menard", Genette has emphasized the importance of the Borgesian intuition that the most delicate and important operation of all those which contribute to the writing of a book is reading it. He concludes his analysis with these words: "The genesis of a work in the time of history and the life of an author is the most contingent and most insignificant moment of its duration ... The time of a book is not the limited time of its writing, but the limitless time of reading and memory. The meaning of books is in front of them and not behind them; it is in us: a book is not a ready-made meaning, a revelation we have to suffer; it is a reservation of forms that are waiting to have some meaning, it is the 'imminence of a revelation that is not yet produced”, and that every one of us has to produce for himself. (p. 105)

Certainly Borges seems to confirm this "approach, of whose validity there is no question" in an essay like "A Note on (toward) Bernard Shaw", where he rejects the notion of fiction as merely a "verbal structure”, a “combinatory game”:

Those who practice this game forget that a book is more than a verbal structure or a series of verbal structures; it is the dialogue it establishes with its reader and the intonation it imposes upon his voice and the changing and durable images it leaves in his memory. The dialogue is infinite ... Literature is not exhaustible, for the sufficient and simple reason that no single book is. A book is not an isolated being: it is a relationship, an axis of innumerable relationships. (Borges, 1962, p. 213)

Indeed the reader seems to determine the text, rather than the text determining our reading:

One literature differs from another, prior or posterior, less because of the text than because of the way in which it is read: if I were granted the possibility of reading any present-day page — this one, for example—as it will be read in the year two thousand, I would know what the literature of the year two thousand will be like. (Borges, 1962, pp. 213-214)

We seem to discover this kind of reader as a writer in the protagonist of "Pierre Menard, Author of the Quixote”: “To be, in some way, Cervantes and reach the Quixote seemed less arduous to him—and, consequently, less interesting - than to go on being Pierre Menard and reach the Quixote through the experiences of Pierre Menard” (Borges, 1962, p. 40). Menard, “author” of the Quixote, is not just a writer, but 
also a reader, when he produces a Quixote identical in text with the original but different, indeed richer, in meaning: "Cervantes' text and Menard's are verbally identical, but the second is almost infinitely richer" (Borges, 1962, p. 42).

Like a reader Menard "copies” a text word for word, but, like a writer, he transforms it. Borges' fiction requires a reader who is both a translator and a creator-or re-creator. Borges (1962) confirms Rodrigues Monegal's discovery of "an aesthetics of fiction based on the reading of the text":

Menard (perhaps without wanting to) has enriched, by means of a new technique, the halting and rudimentary art of reading: this new technique is that of the deliberate anachronism and the erroneous attribution. This technique, whose applications are infinite, prompts us to go through the Odyssey as if it were posterior to the Aeneid ... This technique fills the most placid works with adventure. (p. 44)

The text of the Quixote stays identical, but the way Menard recomposes it changes it completely, transforming it with deliberate anachronism into a symbol or sign of Menard's time, not Cervantes'. But does this technique of deliberately anachronistic reading actualize a revelation in the fiction that otherwise remains merely imminent? Or is not it rather a playful fantasy reading in which we readers find ourselves with powers of creativity autonomous from the text or the writer? An "adventurous" reading, we shall discover, is not just an entertaining fantasy, but one which takes on cosmogonic and apocalyptic risks. The reader as writer will assume fantastic, cosmogonic powers of creation and annihilation in poems like "Amanecer" and stories like “The Circular Ruins”.

Perhaps, as Rodriguez Monegal (1972) asserts, there can be no question of the validity of this approach, but, if so, the consequences are startling. The meaning of a story, "El Aleph” (1957), for example, is not what Borges, the writer, may have intended, a meaning determined within the context of his other stories and essays and limited by the historical moment in which he wrote, but whatever preconceptions and associations the reader brings to the story as a reader from his own personal time and situation. It is impossible-or delusional— to think that the reader ever reads or could read Borges' "El Aleph" and write an essay about "it”- such an object or determined text does not exist—merely a version of "El Aleph" the reader re-writes and invents every time he reads the text of that title. There are as many "El Alephs" as there are readers, and Borges becomes only one of many other readers of his own story. Criticism and scholarship does indeed become a branch of fantastic literature.

\section{Berkeley}

It is hardly surprising that Borges, the radically idealist Borges of an essay like "A New Refutation of Time” (1981) or stories like "Tlon, Ukbar, OrbisTertius” (1981), should deny that the fiction exists as a "verbal structure" or an "object". For the radical idealist Borges, a world of objects or material reality is only possible through a perceiving consciousness that constitutes and sustains a "representation" (in the Berkeleyan sense of framing an "idea”), as in one of several quotations Borges cites from Berkeley:

But, say you, surely there is nothing easier than for me to imagine trees, for instance, in a park, or books existing in a closet, and nobody by to perceive them. I answer, you may so, there is no difficulty in it; but what is all this, I beseech you, more than framing in your mind certain ideas which you call books and trees, and at the same time omitting to frame the idea of any one that may perceive them? But do not you yourself perceive or think them all the while? This therefore is nothing to the purpose: it only shews you have the power of imagining or forming ideas in your mind; but it does not shew that you can conceive it possible the objects of your thought may exist without the mind. (Rodriguez Monegal, 1981, p. 180) 
A previous quotation from Berkeley in the essay "A New Refutation of Time” implies that the work of fiction as an object or work of art does not exist unless it is "perceived" by a reader:

Some truths there are so near and obvious to the mind that a man need only open his eyes to see them. Such I take this important one to be, viz., that all the choir of heaven and furniture of the earth, in a word all those bodies which compose the mighty frame of the world, have not any subsistence without a mind-that their being is to be perceivedor known; that consequently so long as they are not actually perceived by me, or do not exist in my mind or that of any other created spirit, they must either have no existence at all, or else subsist in the mind of some Eternal Spirit-. (Rodriguez Monegal, 1981, p. 181)

This quotation from Berkeley amounts to no less than a metaphysical argument for the priority of the reader, as a constitutive and sustaining consciousness, over the text as an autonomous "object", an object that only exists in so far as it is seen or imagined by a sustaining consciousness, whether that of the writer, the reader, or the eternal spirit. This reader as Berkeleyan eternal spirit might be the ancestor of Genette's and Rodriguez Monegal's reader as writer, whose reading actualizes the "imminence of revelation", a reader who will appear over and over again in Borges' essays and fictions as a dreamer or writer who dreams a vision of the universe into existence.

\section{Cosmogonic and Apocalyptic Reading}

If the reader resembles Berkeley's perceiver, he creates or dreams the universe he exists in, the fiction he reads. When the reader reads she creates little worlds, microcosms. His reading is cosmogonic, world-creating, and creative; no wonder the reader "writes" or re-creates the fiction he reads. Such a Berkeleyaneternal spirit appears in the poem "Dawn" (1981). This poem resembles the type of "meditational poem" familiar to readers of 17th Century English poetry. It is a poem of philosophical speculation, the record or account of a revelation in the form of an idea that has occurred to the poet. Through the poet's use of the first person "I", the reader enacts or re-lives the constitutive mind or consciousness of a blind poet, an insomniac - unable to lose consciousness and sleep-who wanders through the streets of Buenos Aires, sustaining the entire city in his mind, until others awaken and carry on his metaphysical burden. If the poem or fiction resembles an idea, like Berkeley's or Schopenhauer's, it can only exist if it is dreamed into consciousness by an individual dreamer or reader: “...Since ideas are not like marble, everlasting, but ever-renewing like a forest or river, the previous speculation ... dominated my reason and projected the following whim... ” (Rodriguez Monegal, 1981, p. 6) The content of this poem is not the city of Buenos Aires at dawn, but a mental act, a revelation, at first only a presentiment, then an idea of a prior writer or philosopher, which unexpectedly finds renewed existence as it is reformulated and thought in the mind of the poet. There are no emotions or feelings in the poem, only perceptions, memories, acts of reflection and speculation. The poem imitates or enacts a mental process of creating a poem.

Like Berkeley's mind that frames or constitutes "all the choir of heaven and furniture of the earth" (Rodriguez Monegal, 1981, p. 181), the speaker in "Dawn" is an impersonal wanderer who sustains the entire city of Buenos Aires in his consciousness and also threatens it with annihilation if he ceases to constitute or dream it. Perhaps the physical blindness of the speaker (not necessarily just an autobiographical reference) emphasizes the constitutive, fabricating process of perception that makes possible the vision of the city sustained in his “dreaming” (Borges, 1962, p. 208) consciousness. This poem, like many others, moves from revelation, dreaming, and creation to a moment of apocalypse and annihilation, particularly the annihilation of 
personal consciousness. The poet or reader, who reads, and in reading, re-lives and reconstitutes the poem, exhibits cosmogonic and apocalyptic powers of creativity. The city only exists as long and in so far as it is sustained in the wakened consciousness of the poet. Similarly the reader might suppose that the poem, like an idea, only exists in so far as it is read, or rethought, transformed in the mind of a new reader, and, if the reader ceases reading the poem, it ceases to exist.

\section{Visible Unrealities}

Another constitutive, sustaining consciousness appears in the story "The Circular Ruins", where the epigraph after the title, before the story even begins, evokes the reader's cosmogonic, apocalyptic powers as a Reader: "And if he left off dreaming about you... ” (Borges, 1962, p. 45). The writer has left it to the reader to complete this interrupted quotation, and, if he does so, "you would cease to exist". The opening lines of the story — "No one saw him disembark in the unanimous night..." (Borges, 1962, p. 45)—are footnotes to the Berkeleyan quotations above. The protagonist or dreamer of this story is a powerful magician, evocative of a Hermetic magus, who dreams a man into existence only to discover at the end of the story that he too is being dreamed. The magician who dreams a man into existence resembles both a writer and a reader. The infinite regress through which this story is fabricated — the dreamer within a dreamer includes the Reader as Berkeleyan constitutive and sustaining consciousness (the creative "unanimous night" out of which a poem, like "Dawn" or a story like "The Circular Ruins" can emerge). The new element in this myth of dreaming a fiction into existence is the idea that our dreaming is dreamed. The logic of this infinite regress is unavoidable: The reader is dreaming the story into existence, almost as if it was an actual reality, but the reader's dreaming is dreamed, by Borges or by the fiction as a text for the reading. The reader's reading is not a spontaneous evocation of vision, but an artifice, as artificial as the writing of the fiction. The illusion of reality the reader succumbs to is only the result of enchanting himself into taking his "dreamed son" as an autonomous being. The reading would appear to be determined by a prior text or by the writer’s “combinatory games” (Borges, 1962, p. 213) with his verbal structure, not merely the evanescent and vanishing mental vision of the Eternal Spirit's consciousness. As writers and readers the readeris composed of texts and schemata, alphabets and artifacts, not merely mental perceptions and ideas.

We begin to see here in this story, as in the "tremendous conjecture" of "Dawning" that denied or rejected poetics of the poem or fiction as a prior text, repudiated by Borges as a mere "verbal algebra". The magician of "The Circular Ruins" exercises his cosmogonic powers in dreaming another man into existence and "imposing" him on reality:

The purpose that guided him was not impossible, though supernatural. He wanted to dream a man; he wanted to dream him in minute entirety and impose him on reality. This magic project had exhausted the entire expanse of his mind.... (Rodriguez Monegal, 1981, p. 124)

This apparition, nourished by the very mental life of the dreamer, starts out a dream or fiction, but "gradually, he began to accustoming him to reality". The language used in this story for the process of dreaming subtly implies that, if the dreamed man resembles a fiction, the work of fiction is not just a "copy" of reality, but interpenetrates with reality, gradually assuming its own autonomous existence along with the rest of the universe generated by the dreaming Consciousness. The climax and conclusion of the story is a sudden revelation that contradicts this illusion of actual presence or existence. The dreamer encounters a "visible 
unreality” when the fire encircling the ruins of the burned temple does not burn but only caresses his flesh:

He walked toward the sheets of flame. They did not bite his flesh, they caressed him and flooded him without heat or combustion. With relief, with humiliation, with terror, he understood that he also was an illusion, that someone was dreaming him. (Rodriguez Monegal, 1981, p. 127)

The Magician in “The Circular Ruins” anticipates another Magician in Borges’ essay (devoted to a history of the idea of infinite regress), “Avatars of the Tortoise”:

"The greatest magician (Novalis has memorably written) would be the one who would cast over himself a spell so complete that he would take his own phantasmagorias as autonomous appearances. Would not this be our case?” I conjecture that this is so. We (the undivided divinity operating within us) have dreamt the world. We have dreamt it as firm, mysterious, visible, ubiquitous in space and durable in time; but in its architecture we have allowed tenuous and eternal crevices of unreason which tell us it is false. (Borges, 1962, p. 208)

This architecture of the dream is the text of the fiction, a text that requires artifice in our fabrication. No matter how much Borges rejects and repudiates the concept of the fiction as a "mere verbal algebra," the Writer and Reader, like the dreamer in "The Circular Ruins", resemble Novalis's Magician, and certain poems of philosophical speculation and stories like "The Circular Ruins" constructed out of philosophical puzzles and paradoxes resemble those "philosophies” Borges evokes in "Avatars of the Tortoise":

It is venturesome to think that a coordination of words (philosophies are nothing more than that) can resemble the universe very much. It is also venturesome to think that of all these illustrious co-ordinations, one of them-at least in an infinitesimal way_does not resemble the universe a bit more than the others. I have examined those which enjoy a certain prestige; I venture to affirm that only in the one formulated by Schopenhauer have I recognized some trait of the universe. According to this doctrine, the world is a fabrication of the will. Art-always-requires visible unrealities. Let it suffice for me to mention one: the metaphorical or numerous or carefully accidental diction of the interlocutors in a drama ... Let us admit what all idealists admit: the hallucinatory nature of the world. Let us do what no idealist has done: seek unrealities which confirm that nature. We shall find them, I believe, in the antinomies of Kant and in the dialectic of Zeno. (Borges, 1962, pp. 207-208)

That is, the universe should exhibit, like the fiction "The Circular Ruins", the "visible unrealities" of Zeno's dialectic, the principle of infinite regress.

\section{Conclusions}

In the dreamed and dreaming world of Borges' fiction, objects, ideas, and people do not retain their separate roles and identities but merge, exchange roles, and symbolize each other through such co-ordinations of words as the avatars of infinite regress he discusses in "Avatars of the Tortoise". One idea or poetics, like dreaming, can resemble or require it's opposite. The reader requires a prior text to copy, translate, and recreate, and that text only exists as a fictional microcosm in so far as it is being read by a Reader who is able to actualize the revelation only imminent within it.

\section{References}

Borges, J. L. (1957). El Aleph (The Aleph). Buenos Aires: Emece.

Borges, J. L. (1960). Otras inquisiciones (Other inquisitions). Buenos Aires: Emece.

Borges, J. L. (1962). Labyrinths: Selected stories and other writings. D. A. Yates, \& J. E. Irby, (Eds.). New York: A New Directions Book.

Borges, J. L. (1966). Other inquisitions: 1937-1952. (R. Simms, Trans.). New York: Washington Square Press.

Borges, J. L. (1967). A personal anthology. A. Kerrigan, (Ed.). New York: Grove Press. 
Borges, J. L. (1970). The Alephand other stories 1933-1969: Together with commentaries and an autobiographical essay. (N. T. di. Giovanni, (Ed.), Trans.).New York: Bantam.

McAllister, R. (1962). Borges' "El Aleph” and Poe's “The Fall of the House of Usher: Two studies in Gothic romance”. In A. R. Becker (Ed.), Visions of the fantastic. Westport, Ct.: Greenwood Press.

Rodriguez Monegal, E. (1972). Borges: The Reader as Writer. TriQuarterly, 25, 102-143.

Rodriguez Monegal, E., \& Reid, A. (Eds.). (1981). Borges, a reader: A selection from the writings of Jorge Luis Borges. New York: Dutton. 